SJ Quinney College of Law, University of Utah

Utah Law Digital Commons

$8-2020$

Science Fiction and the Law: A New Wigmorian Bibliography

Jorge L. Contreras

Follow this and additional works at: https://dc.law.utah.edu/scholarship

Part of the Other Law Commons 


\title{
SCIENCE FICTION AND THE LAW: A NEW WIGMORIAN BIBLIOGRAPHY
}

\author{
Jorge L. Contreras ${ }^{1}$
}

Draft 1 Aug. 2020

\begin{abstract}
In 1908, Dean John Henry Wigmore compiled a list of novels that no lawyer could "afford to ignore". Wigmore's list, taken up by Professor Richard Weisberg in the 1970s, catalogs one hundred novels, stories and dramatic works from Antigone to The Merchant of Venice to Native Son, each of which portrays or offers insight into the legal system or the practice of law. Weisberg's updated list also includes a compilation of critical studies in the then-emerging law and literature movement. This article undertakes a similar bibliographic exercise with respect to law and the literature of science fiction. While science fiction, as a literary genre, has its detractors, it cannot be denied that science fiction stories - whether in books, short stories, films or television shows - reach a vast audience and, for better or worse, influence popular perceptions and understanding of science and technology issues. Likewise, science fiction narratives that portray legal regimes directed at new and unsolved problems (prescribing relations between alien races, governing sentient machines, regulating human genetic modification) can help judges, lawyers and policy makers to consider the hypothetical effects of such regulations in the real world. Accordingly, this article offers a list of fifty science fiction works that address legal issues, classified according to doctrinal themes, as well as a compilation of academic literature addressing issues of law in science fiction. It is hoped that the materials compiled here will serve as a useful resource for legal practitioners, policy makers and educators as they grapple with ever increasing legal challenges brought about by the rapid evolution of science and technology.
\end{abstract}

1 J.D. (Harvard Law School), B.S.E.E., B.A. (Rice University). Presidential Scholar and Professor of Law, University of Utah S.J. Quinney College of Law, Adjunct Professor, Department of Human Genetics, University of Utah School of Medicine. 


\section{WIGMORE'S LEGAL NOVELS}

In 1908, Dean John Henry Wigmore, of evidentiary treatise fame, ${ }^{2}$ compiled a list of 377 novels that no lawyer could "afford to ignore". ${ }^{3}$ The list, populated largely by nineteenth century American, British and Continental novels, included works by the likes of Honoré de Balzac, Charles Dickens, Alexandre Dumas, George Eliot, Thomas Hardy, Nathaniel Hawthorne, Victor Hugo, Leo Tolstoi and Mark Twain, as well as earlier notables like Bunyan and Cervantes. But Wigmore's purpose in compiling his list was not merely to edify; he believed it imperative that lawyers understand how their profession was perceived by the public:

With these [novels] every lawyer must be acquainted, not merely because of his general duty as a cultivated man, but because of his special professional duty to be familiar with those features of his profession which have been taken up into general thought and literature. ${ }^{4}$

Wigmore acknowledges that the principles of legal practice can be learned from essays, and biographical and historical works. But the novel, he contends, immerses the reader in its subject with an immediacy and empathy that are difficult to achieve through more didactic writings. Thus:

This deepest sense of their reality we shall get only in the novels... We must go to "Bleak House" to learn the real meaning of chancery's delays, to "Oliver Twist" to see the actual system of police and petty justice in London, to "Pickwick Papers" to appreciate the technicalities of civil justice... There is in fact hardly an end to the line of boundary where history and law unite in the pages of the novelist. ${ }^{5}$

Wigmore's list contains more than a few works of dubious literary merit. Though he deliberately excluded "the ordinary detective story", ${ }^{6}$ he included more

2 JOHN HENRY WIGMORE, A TREATISE ON THE SYSTEM OF EVIDENCE IN TRIALS AT COMMON LAW INCLUDING THE STATUTES AND JUDICIAL DECISION OF ALL JURISDICTIONS OF THE UNITED STATES (1908) (this treatise, popularly known as Wigmore on Evidence, has been released in numerous editions and remains in print today).

${ }^{3}$ John H. Wigmore, A List of Legal Novels, 2 ILL. L. REV. 574, 575 (1908). Wigmore reports that he began his compilation effort in 1898 with a list of 50 titles. Id. at 586 . By 1900 he had expanded the list to about 100 titles and published it in a publication entitled The Brief, Vol. II, No. 2, p. 124, January, 1900. Id. Over the next few years, his colleagues and students at Northwestern Law School, as well as other readers, helped him to bolster the list to 377 titles. Id. at 586-87.

${ }^{4}$ Wigmore 1908 , supra note 3 , at 575-76.

${ }^{5} \mathrm{Id}$. at $577-79$.

${ }^{6} \mathrm{Id}$. at 575 . 
than a few potboilers of Victorian literature penned by authors such as Arthur Conan Doyle, Walter Scott, H. Rider Haggard, Edward Bulwer-Lytton ${ }^{7}$ and a host of names unrecognizable to the modern reader. They are the John Grishams and Scott Turows of the past - purveyors of popular novels intended for mass consumption, filled with interesting characters and plot twists, and along the way educating readers about the law, the legal system and the professional bar.

In 1922, without much explanation, Wigmore shortened his list to 103 titles (rounding to 100 for purposes of description), culling and trimming works that were of lesser significance. ${ }^{8}$

In 1976, Professor Richard Weisberg, one of the founders of the "law and literature" movement, ${ }^{9}$ updated Wigmore's list. ${ }^{10}$ Weisberg added more recent works (To Kill a Mockingbird, The Stranger, The Trial, Native Son), and some that were only appreciated after Wigmore's day (e.g., Melville's Billy Budd, now a staple of the law and literature canon). He also included authors whose translation into English was more recent (Dostoyevsky, Gogol), and a few prominent figures from antiquity (Ovid, Aeschelus, Sophocles, plus the anonymous authors of the Icelandic sagas and the Book of Esther). Weisberg also expanded the scope of the list to include both short stories and dramatic works (namely the works of Shakespeare, another staple on today's law and literature syllabi). To make space for these additions, Weisberg trimmed many of the forgotten and less accomplished works on Wigmore's list, including everything by Conan Doyle, Scott, Haggard, and Bulwer-Lytton.

But Weisberg's update was no pedantic curatorial exercise. He felt that in the tumultuous 1970s Wigmore's list was needed more than ever. A change had occurred in the legal profession. "There can be little doubt," Weisberg wrote, "that individual lawyers remain as literate as they were in Wigmore's day; but legal institutions, including surprisingly the legal academy, have all but broken off from their humanistic roots." 11 As evidence of the moral drift afflicting the legal enterprise, Weisberg pointed to Watergate and the "value-free" machinations of

\footnotetext{
${ }^{7}$ Sir Edward George Bulwer-Lytton is best-known today as the author of the opening line "It was a dark and stormy night..." PAUL CLIFFORD (1830), and consequently as the namesake for the Bulwer-Lytton Fiction Contest sponsored by San Jose State University, which awards prizes to authors who can concoct equally terrible opening lines. https://www.bulwer-lytton.com/about. The "line" in its full glory reads: "It was a dark and stormy night; the rain fell in torrents - except at occasional intervals, when it was checked by a violent gust of wind which swept up the streets (for it is in London that our scene lies), rattling along the housetops, and fiercely agitating the scanty flame of the lamps that struggled against the darkness."

${ }^{8}$ John H. Wigmore, A List of 100 Legal Novels, 17 ILL. L. REV 26 (1922).

${ }^{9}$ For a concise history of the law and literature movement and its debt to Wigmore's legacy, see Richard H. Weisberg, Wigmore and the Law and Literature Movement, 21 L. \& LIT. 129 (2009).

${ }^{10}$ Richard H. Weisberg, Wigmore's Legal Novels Revisited: New Resources for the Expansive Lawyer, 71 Nw. U. L. REV. 17 (1976).

${ }^{11}$ Id. at $17-18$.
} 
members of the bar like Spiro Agnew and Richard Nixon. ${ }^{12}$ Weisberg hoped that his updated list would provide lawyers with not only a view of the public perception of their profession, but with an ethical compass to guide their actions.

In addition to the updated version of Wigmore's works of fiction, Weisberg included a list of twenty-six "critical works" that examined the role of law in literature. These ranged from Ephraim London's classic 1960 text The Law as Literature; The Law in Literature to several entries in a 1975 issue of the Rutgers Law Review devoted to law and the humanities. In 2009, Weisberg again revisited Wigmore's list and continued to find value in it. Reading these works, he contended, offers the lawyer "(1) skepticism about authoritative rationales that seem intuitively wrong; (2) an ability to link ethics to one's rhetorical performance; (3) excellence in listening and writing skills; and (4) an openness to the perspective of individuals whose way of seeing the world places them "outside" the scheme of conventional legal understanding." 13 Thus, after more than a century, the works collected by Wigmore and his followers continue to inform and inspire lawyers, and to populate reading lists, around the world.

\section{SCIENCE FICTION AND THE LAW}

Science fiction is a broad thematic category that includes works (literary and, increasingly, film and television) that contain elements that are possible within the known rules of the universe, but do not exist in the present day. ${ }^{14}$ As writer Norman Spinrad put it, science fiction works include "a speculative element belonging to the sphere of the "could be, but isn't". ${ }^{15}$ Science fiction is thus distinguished from works of fantasy and mythology (The Odyssey, Lord of the Rings) in which no (even remotely) plausible explanation is given to the extraordinary; they rely on magic or acts of the gods; as Spinrad observes, they "openly and knowingly contradict[] what we presently consider the "possible." 16 Science fiction, on the other hand, at least tries to explain its eccentricities by reference to known scientific principles, no matter how outlandish or implausible. ${ }^{17}$

${ }^{12}$ Id. at 18. Spiro Agnew, Vice President of the United States from 1969-73, resigned from office after allegations of tax fraud and corruption were made against him. Richard Nixon, $37^{\text {th }}$ President of the United States (1969-1974), resigned from office following the Watergate scandal.

${ }^{13}$ Weisberg 2009, supra note 9, at 140.

${ }^{14}$ See Adam Roberts, The History of Science Fiction 1-20 (2006) (defining "science fiction").

${ }^{15}$ Norman SpinRad, Science Fiction In The Real World xiv (1990) (quoted in Bruce L. Rockwood, Science Fiction and Law: New Possibilities, 23 LegAL STUD. F. 267, 268 n.5 (1999)).

${ }^{16} I d$. Another genre that is distinct from science fiction is allegory, in which extraordinary events - talking animals, genies granting wishes, people growing and shrinking -- are not explained at all. Thus works like Swift's Gulliver's Travels, Carroll's Through the Looking Glass, Orwell's Animal Farm and Yorgos Lanthimos's recent film The Lobster (2015), which present fantastical situations purely to comment on current political events, are not science fiction.

${ }^{17}$ The dividing line between science fiction and fantasy is often blurred. For example, in the popular Star Wars films, the omnipresent "Force" was originally presented as a quasireligious/mythical phenomenon (the phrase "May the Force Be With You" echoing that of the Christian liturgy). Yet when the producers sought to add scientific credibility to the otherwise 
As a literary genre, science fiction has an uneven reputation - filled with plotdriven narratives akin to Wigmore's "ordinary detective stor[ies]", it is derisively (and affectionately) said that the "golden age" of science fiction is twelve. ${ }^{18}$ With a few exceptions, writers of science fiction do not win prestigious literary awards, ${ }^{19}$ and those that do are best known for other works. ${ }^{20}$ Only a handful of authors who are known primarily for their science fiction -- Margaret Atwood and George Orwell in particular -- have earned places in the mainstream literary pantheon.

Yet science fiction has, for at least half a century, been the subject of serious scholarly attention. In 1958, the Modern Language Association held its first academic seminar on science fiction, ${ }^{21}$ and by 1972 two annotated bibliographies of science fiction criticism were published. ${ }^{22}$ Science fiction scholarship has drawn upon academic disciplines such as political science, gender/LGBQ studies, critical theory, linguistics, and, more recently, law. ${ }^{23}$

As it turns out, science fiction has much to say about today's world and the legal systems that govern it. As Bruce Rockwood observes in the introduction to a 1999 symposium, "Science Fiction ... explores political, legal and ideological alternatives, commenting upon both our present and possible futures." 24 Science fiction authors extrapolate from the issues of the day, predicting what might happen if the world continues on one course or another. The genre allows them to speculate about the consequences of new technologies and discoveries. In many cases, their predictions have been realized - from Jules Verne's flying ships and submarines to the communicators used by Starfleet. But the future predicted by science fiction has

metaphysical Force in The Phantom Menace (1999) by attributing it to the action of microscopic organisms known as "midichlorians", fans revolted. See Graig Stephens, The Phantom Menace: The Good, The Bad, and The Midi-chlorians, Fansided, Nov. 18, 2018, https://dorksideoftheforce.com/2018/11/08/phantom-menace-good-bad-midichlorians/.

Another work that is often classified as science fiction, but which is closer to fantasy, is N.K. Jemisin's Broken Earth series, in which a select group of humans can mentally control the earth's seismological instability, but with little by way of scientific explanation.

${ }^{18}$ See Rockwood, supra note 15, at 269 n.12 (discussing the origin of this saying, attributed alternately to science fiction writers Isaac Asimov and Terry Carr).

${ }^{19}$ Science fiction has its own awards universe, consisting of the Nebula and Hugo awards, as well as other lesser accolades.

${ }^{20}$ Doris Lessing, the author of the five-volume science fiction series Canopus in Argos, won the Nobel Prize in Literature (2007). Kazuo Ishiguro, the author of Never Let Me Go (this list) won the Nobel Prize in Literature (2017).

${ }^{21}$ Marshall B. Tymn, Roger C. Schlobin, Lloyd W. Currey, A Research Guide to SCIENCE FICTION STUDIES (1977).

${ }^{22}$ Thomas D. Clarenson, Science Fiction Criticism: An Annotated Checklist (1972); Robert E Briney \& Edward Wood, SF Bibliographies: An Annotated Bibliography of Bibliographic Works on Science Fiction and Fantasy Fiction (1972).

${ }^{23}$ For a discussion of critical scholarship that relates to science fiction and the law, see Section III.D, infra.

${ }^{24}$ Rockwood, supra note 15, at 271. See also Orna Ben-Naftali and Zvi Triger, The Human Conditioning: International Law and Science-Fiction, 14 L. CUlture \& HuMANITIES 6, 15 (2018) (science fiction "focuses on our present ideological, moral and legal disputes and in playing them out in imagined futures, proposes both criticism and alternatives.") 
not always been rosy. The post-war era saw a boom in literature envisioning new and terrifying totalitarian states, most famously illustrated by Orwell's Nineteen Eighty-Four. In the 1950s, science fiction offered chilling predictions about Abomb induced genetic mutations (Godzilla, ${ }^{25}$ Them $^{26}$ ) and nuclear apocalypse (On the Beach, ${ }^{27}$ Alas Babylon $\left.{ }^{28}\right)$. In the 1970s, fear of overpopulation and ecological disaster led to films such as Silent Running ${ }^{29}$ and Soylent Green. ${ }^{30}$ The emergence of personal computers and computer games in the 1980s gave rise to the cyberpunk movement exemplified by works like Neuromancer ${ }^{31}$ and Snow Crash. ${ }^{32}$ And the rise of the biotechnology industry in the 1990s inspired tales of genetic engineering gone awry, splendid examples of which can be found in the novel Jurassic Park ${ }^{33}$ and the film Gattaca. ${ }^{34}$ It is likely that much of what the public knows about space travel, genetic engineering, human cloning, nuclear weapons, nanotechnology, artificial intelligence, virtual reality and every other technological development of the last century is gleaned largely from works of science fiction. ${ }^{35}$

Science fiction offers fertile ground for speculation about the future of technology and its effect on human society. As such, it is an ideal medium in which to consider how the law can and should develop in the face of technological change. Lawyers, judges and law professors thrive on hypothetical scenarios. Within the context of a science fiction story, an author can postulate a law or rule that responds to a scientific or technological discovery in a way that extends far beyond the classroom thought experiment.

When a judge or a policy maker is faced with the necessity for a new legal rule, he or she typically considers, in addition to formal analytical factors - economic cost, consistency with existing rules, administrability, etc. - his or her own personal experience. As critical legal scholars have demonstrated, this inherently human tendency is unavoidable and, in many cases, desirable. Thus, in thinking about mortgage reform, the policy maker invariably considers how such a reform would affect his or her monthly mortgage payments, or those of a parent, sibling or child. In contemplating the length of a sentence for various offenses, the judge cannot help but think how he or she has spent, or would spend, the number of years that the accused will be put away.

${ }^{25}$ Godzilla (1954)

${ }^{26}$ Gordon Douglas (dir.), Them (1954).

${ }^{27}$ Nevil Shute, On the Beach (1957).

${ }^{28}$ Pat Frank, Alas, Babylon (1959).

${ }^{29}$ Douglas Trumbull (dir.), Silent Running (1972).

${ }^{30}$ Richard Fleischer (dir.), Soylent Green (1973).

${ }^{31}$ William Gibson, Neuromancer (1984).

${ }^{32}$ Neal Stephenson, Snow Crash (1992).

${ }^{33}$ Michael Crichton, Jurassic Park (1990).

${ }^{34}$ Andrew Niccol, Gattaca (1997).

${ }^{35}$ Science fiction is popular. Of the twenty top-grossing films of all time (adjusted to 2020 dollars), eight (five from the Star Wars franchise alone) are squarely in the science fiction camp. Box Office Mojo, Top Lifetime Adjusted Grosses (Data as of Jun 16, 2020), https://www.boxofficemojo.com/chart/top_lifetime_gross_adjusted/?adjust_gross_to=2020\&ref_= bo_cso_ac. 
But in the case of new technologies and discoveries, there are few personal experiences to draw from. When we consider regulating human gene editing, or orbital weapons systems, or cerebral implants, personal experience fails us. Not only do we lack any direct experience with the technology, but we have little idea how different regulatory regimes would play out. Here is where science fiction can help.

Science fiction offers the ultimate legal hypothetical. It is not only analytical, as a white paper or law review article can be, but emotive. It portrays characters living with the consequences of different regulatory and legal regimes. And if the characters are believable, and the legal rules are plausible, then "experience", as it is, can be simulated where none existed before. Works of science fiction thus serve as extended thought experiments, the best of which achieve character empathy that can give purchase to policy arguments and analysis.

Take human genetic enhancement. Today, this technology does not exist outside of the laboratory, though there is a teeming bioethics and legal literature discussing its potential regulation. Part of the impetus behind this policy interest comes from the vast fictional catalog of literature touching the subject. What policy maker, let alone academic, has not considered the dystopian vision of the 1997 film Gattaca when analyzing the regulation of genetic engineering? Or the corporate excesses described in Atwood's Oryx and Crake or Crichton's NEXT?

Fiction, yes. But convincing enough to give pause, and to help the reader envision possible scenarios that could evolve. Thus, as Wigmore wrote with respect to the literature of the law more generally, "the lawyer, whose highest problems call for a perfect understanding of human character and a skillful use of this knowledge, must ever expect to seek in fiction as in an encyclopedia, that learning which he cannot hope to compass in his own limited experience". ${ }^{36}$

\section{COMPILING A LIST OF LEGAL SCIENCE FiCTION WORKS}

\section{A. Substantive Selection Criteria}

If we accept the need, or at least the utility, of a Wigmore-style list of legal science fiction works, we must next ask how we should go about compiling such a list. Following the method of Wigmore and Weisberg, some selection criteria must be developed. As Wigmore asks, "Where shall the line be drawn?" 37

First, the list should include only works of science fiction. Though there are several definitions, the one proposed above - works that contain elements (settings, societies, technologies) that are possible within the known rules of the universe, but

${ }^{36}$ Wigmore 1908 , supra note 3 , at 580.

${ }^{37}$ Id. at 574 . 
do not exist in the present day -- should suffice. This means that a large number of popular fantasy, superhero, ${ }^{38}$ mythological, horror ${ }^{39}$ and similar works, including many that contain legal themes (e.g., Game of Thrones) must be omitted. Even important allegorical works such as Animal Farm must reluctantly be excluded from such a list. ${ }^{40}$

Second, a listed work must contain a significant legal element. The story need not be devoted entirely to a legal dispute or issue, but the legal element must form at least a significant aspect of the plot or the backdrop to the story. Thus, the 1976 film Logan's Run is largely a pursuit-adventure tale ("Stop, runner!"), but it is premised on a society's overriding directive that everyone who reaches the age of thirty must submit to ritual execution. Similar motivating rules exist in The Hunger Games (subsidiary districts must each send "tribute" to the Capitol for gladiatorial combat), Blade Runner (replicants are not allowed to return to Earth), and many other science fiction stories. While the stories themselves do not dwell on the minutiae of these rules, the rules form an essential backdrop to the action of the plot, and the implications of these novel legal systems can be experienced in some detail.

${ }^{38}$ Superhero stories - originating in comic books and today dominating the film industry -present a tricky definitional conundrum. In some cases, the "explanation" for the superpowers possessed by heroes and villains is purely magical or mythological (e.g., Thor, Wonder Woman, Aquaman). But in other cases, there is a putative scientific rationale for these powers (e.g., Spiderman was bitten by a radioactive spider, Superman was born on another planet, the X-men possess genetic mutations). Yet despite the use of scientific-sounding vocabulary, these explanations are not scientific at all. Nothing about Superman's birth on the planet Krypton explains why he can fly for sustained periods, stop bullets with his hands or see through walls. Nor is there any explanation for his complete collapse in the presence of kryptonite (after all, the inhabitants of planet Krypton were surrounded by the element and did not exist in a state of constant incapacitation). Though one may scoff at comic book science-babble, it is no less explanatory than the warp drive or transporters. Nothing about these technologies is even remotely plausible based on today's scientific understanding, so why is Star Trek a revered member of the science fiction pantheon while Superman falls outside of the category entirely? In this case, there is probably no better answer than custom. Because a space ship traveling at very fast speeds seems more scientifically plausible than a man doing so, we classify Star Trek as science fiction, but not Superman. After all, as observed by Arthur C. Clarke, "Any sufficiently advanced technology is indistinguishable from magic." Arthur C. Clarke, Hazards of Prophecy: The Failure of Imagination in Profiles of THE FutUre: An INQUiRY INTO the Limits of THE Possible 14 (1962) (this adage has become known as Clarke's Third Law). See also n.15, supra (discussing the Force).

${ }^{39}$ The zombie movie presents another interesting conundrum. Traditionally, zombies -- corpses reanimated through occult or supernatural means -- fall into the realm of horror and lack a scientific element. However, in recent years several films in the "zombie" genre have sought to explain the animation of corpses through pseudo-scientific explanations, usually some type of infectious agent (e.g., The Walking Dead (2010-present), World War Z (2013), Train to Buson (2016), etc.). For classification purposes, I considered "viral zombie" stories to be science fiction, such as 28 Days Later (2002), which involves the rapid conversion of living individuals into rabid monsters via a "rage" virus.

${ }^{40}$ See n.16, supra (discussing allegory). Interestingly, both the Game of Thrones books and Animal Farm, squarely within the fantasy and allegorical camps, were written by authors (George R. R. Martin and George Orwell, respectively) who have also written significant works of science fiction. 
This being said, simply depicting contemporary legal issues in a futuristic or alien setting is not enough to qualify for listing. For example, fighting conventional crimes using advanced technologies (e.g., the sentient car in Knight Rider) or a mechanized police force (RoboCop) do not make the grade. Likewise, a story describing an otherwise conventional murder on a remote space station, while qualifying as science fiction, is probably not sufficiently legal to merit inclusion on a list of legal science fiction. To do so, the off-world aspects of the murder (its motives, method or investigation) must foster consideration of not only the science fiction trappings of the story, but its legal aspects. Thus, is the murder of an alien treated differently than the murder of a human? What about an android? These plot twists add a speculative dimension to the legal aspect of the story, and thus merit inclusion on the list.

Likewise, stories concerning the waging of war, political intrigue, and government oppression, even when played out in alien or futuristic settings, may not qualify as "legal" science fiction unless the issues go beyond those that are found in similar stories that take place back home. For example, though Heinlein's classic Starship Troopers pits humans against formidable alien foes, most of the plot elements can be found in more conventional war stories.

By the same token, a story that adopts the trappings of the legal process for other reasons, such as the kangaroo trial of humanity conducted by the alien entity Q in Star Trek TNG "Encounter at Farpoint" (1987) is not a trial in any real sense of the word. Thus, despite the fetching judicial robes and courtroom setting, the episode does not address legal issues in a meaningful sense.

Third, as both Wigmore and Weisberg teach, the work should have achieved some degree of public recognition in order to be recommended broadly as an exemplar of its class. For science fiction works, this recognition can take the form of awards, inclusion in anthologies, discussion in the secondary/scholarly literature, ${ }^{41}$ and, in the case of television series, continued availability via popular streaming channels. Nevertheless, there is necessarily a subjective element to this determination, and I do not pretend to shed my personal preferences or experience in compiling this list. Thus, while I have avoided works that seem too recent to have withstood the test of time, I have included two television series from the past five years - Westworld and Black Mirror - because of their strong legal themes and high viewership.

On the other hand, I have included some lesser-known works as well. For example, the 2003 short film The Second Renaissance by Japanese animator Mahiro Maeda, which is included on the DVD The Animatrix, a moderately obscure member of the Matrix franchise. I selected The Second Renaissance in lieu of any of the far better known Matrix films because it is a legal tour de force, detailing the laws and political pressures that led to the dystopian, machine-ruled world of the

${ }^{41}$ One science fiction work, Anthony Burgess's A Clockwork Orange (1962), even made it onto Weisberg's 1977 revision of Wigmore's list. 
films. It is, in effect, a parable of racial oppression - man versus machine - in which the oppressed eventually rise up and prevail, with hideous consequences for the oppressors. Thus, while the work is little known today, I would encourage the curious to seek it out.

\section{B. Technical Selection Criteria}

As for the types of works included, I have taken an expansive view. Novels and short stories are included, as they are on the Wigmore-Weisberg list. But given the tremendous reach and impact of television and film today, it would be myopic not to include these works as well. Some of the best known science fiction works are films, and these are listed by director rather than screenwriter, in accordance with industry practice.

Television series present a challenge. Star Trek, perhaps the most extensive science fiction franchise of all time, over its fifty-plus year history has included nine television series, thirteen feature films and dozens of books - nearly a thousand different stories/plots have emerged in the Star Trek universe. While these exist in a common universe with key shared elements (the United Federation of Planets, the Prime Directive, the major alien species), they span hundreds of years of future history, dozens of major characters and thousands of story lines. With respect to series like Star Trek, in which each episode has a self-contained story line, and in which the quality of the episode is often dependent on its screenwriter(s), I have treated each episode as a unique work identified by its screenwriter(s). ${ }^{42}$

In contrast, a series like Westworld has a continuous story arc over each season. Individual episodes may introduce self-contained story units, but the overall plot line occurs over a season, rather than an episode. As a result, I list the entire first season of Westworld as a single entry (combined with its precursor 1973 film).

In many cases, multiple versions of a work exist. Thus, a book or a story may be adapted for film or television, and -- less common -- a film may be "novelized" as a book. In compiling this list, I have listed the version of a work that is either best known, or which best captures the legal element that is of interest. If two versions of a work are well-known and address the legal element, I have generally listed the earlier version. If the work exists in a significant secondary version, I note that in a footnote. Thus, with respect to Kazuo Ishiguro's poignant story of human clones, Never Let Me Go, I have listed the 2005 novel, with a note referencing the respectable 2010 film starring Keira Knightley. However, I list Ridley Scott's 1982 noir masterpiece Blade Runner, with a note referencing Philip K. Dick's 1968 novel, Do Androids Dream of Electric Sheep, as the film is far better

42 In addition to its creator Gene Roddenberry, Star Trek included many science fiction luminaries among its writers. These included Harlan Ellison ("City on the Edge of Forever"), Theodore Sturgeon ("Amok Time", "Shore Leave") Robert Bloch ("What Are Little Girls Made Of?", "Catspaw", "Wolf in the Fold"), Frederic Brown ("Arena") and Norman Spinrad ("The Doomsday Machine"). 
known than the novel, and the novel bears little resemblance to the script. ${ }^{43}$ In cases in which a film adaptation of a book or story is of far lower quality than the original, I have not listed the adaptation at all. ${ }^{44}$

A diversity of viewpoints is also important in a list like this. Science fiction, it is well-known, was for much of its early history dominated by white, male authors. ${ }^{45}$ Women began to emerge as meaningful voices in the genre in the $1950 \mathrm{~s}$, but a watershed occurred in the 1970s when Ursula K. Le Guin began to win the major science fiction literary prizes. Other significant female authors including Joanna Russ, Doris Lessing, Octavia Butler and Margaret Atwood emerged soon thereafter. In the last twenty years, women have won a majority of the Nebula awards for the best science fiction novel (as well as half of the Hugo awards for the best science fiction/fantasy novel). ${ }^{46}$ The trajectory of people of color and LGBTQ people who write science fiction has followed a similar trajectory. In the 1960s, Samuel R. Delaney stood out as the only prominent openly gay or AfricanAmerican writing in the genre. Today, science fiction has become a vehicle for expression by authors of many different perspectives. This list seeks to be representative of the diversity within the genre, while at the same time adhering to the thematic framework described above.

The final consideration in compiling a list such as this is its overall length. As noted above, Wigmore's original collection of legal novels was fifty long. He expanded it to nearly four hundred over the next decade, then reined it in to a hundred in 1922. Weisberg preserved the 100-work limit in 1977, though expanding the scope to encompass both stories and plays. Science fiction is but one genre of literature. As such, I feel that fifty is the right length for this list. I could easily list a hundred or more works, but doing so would begin, I feel, to include works in which the legal element is more marginal. So, at least for the moment, it is fifty.

In order to fit everything into a list of fifty, it was necessary to omit numerous titles that otherwise would have qualified. In selecting which titles to omit, I considered various factors, including the degree to which legal issues were featured, the treatment of similar themes in other titles (avoiding thematic duplication), a

${ }^{43}$ Blade Runner is well-known for the significant differences between its theatrical release and its director's cut - differences that change the outcome and overall gestalt of the film.

${ }^{44}$ For example, the 2004 film adaptation of Asimov's classic book I, Robot starring Will Smith bears so little resemblance to the original that I find no reason to acknowledge its existence. And the 2006 rotoscope animated version of Philip K. Dick's A Scanner Darkly (1977), though faithful to the book's plot, is so painful to watch (with partially animated versions of Keanu Reeves, Robert Downey Jr., Woody Harrelson, and Winona Ryder) that I would not inflict it on anyone.

${ }^{45}$ See Helen Merrick, Gender in Science Fiction in The Cambridge Companion to Science Fiction 241 (Edward James \& Faran Mendleson, eds., 2003). But see Geek's Guide to the Galaxy, The History of Women in Sci-Fi Isn't What You Think, Wired, Feb. 2, 2019 (noting that 15\% of "pulp" science fiction authors were women).

${ }^{46}$ See Science Fiction \& Fantasy Writers of America, Inc., Nebula Awards - Awards by Year, https://nebulas.sfwa.org/awards-by-year/, The Hugo Awards, Hugo Awards by Year, http://www.thehugoawards.org/hugo-history/. 
diversity of authorial voices, and the degree to which titles are known and respected among fans and the general public. Of necessity, these choices were highly subjective, and I look forward to readers' views regarding the choices made.

\section{Plot Categories}

The final innovation of Wigmore's list was the classification of each work within a four-part schema. ${ }^{47}$ Weisberg preserves but partially revises Wigmore's classification system, seeking "to indicate in which specific ways literary artists have demonstrated an interest in the law."48 As such, the Wigmore-Weisberg classification scheme is largely structural in nature; it groups works based on the manner in which the authors have integrated legal elements into them. The four classifications can be summarized as follows:

A. Procedural - the work depicts a full legal procedure, such as a trial or investigation (e.g., the trial in The Merchant of Venice);

B. Character - a lawyer is a central figure in the plot and depicted in his/her "out of court dealings with reality" 49 (e.g., Atticus Finch in To Kill a Mockingbird);

C. Doctrinal - a specific body of laws, often a single statute or system of procedures, is an organizing structural principle (e.g., the inheritance dispute in King Lear);

D. Thematic - less patently "legal" works which nonetheless powerfully evoke the deepest problems raised by the relationship of the law to the individual or society (e.g., Wright's Native Son, which "forcefully presents the difficulties experienced by a black man whose actions displace him from the protected area of institutional benignity). ${ }^{50}$

While I emulate Wigmore/Weisberg in adopting a classification system for the works selected, I do not follow their structural approach. In the case of science fiction, there are precious few legal procedurals, and even fewer notable works that feature lawyers as their principal characters. This leaves the large majority of works for Wigmore/Weisberg categories C and D. But are future laws that discriminate against alien life forms usefully compared to the "thought crime" of Nineteen Eighty-Four or the tribute system of The Hunger Games?

${ }^{47}$ Wigmore 1908, supra note 3, at 574 ("As for any definition or further subdividing of the "legal" novel, it is perhaps unprofitable and certainly difficult, being decidedly open to difference of taste and opinion. Nevertheless, for those who care to pick and choose, there may be noted, in the rough, four kinds...")

${ }^{48}$ Weisberg 1976, supra note 10, at 18. See also id. at 19 ("the categories remain helpful by directing the professional reader to the predominating legal aspect of each text. Furthermore, reading works in each category over a relatively short period of time will allow the follower of the list to take note of the remarkable similarities in works otherwise displaying greatly varied styles and thematic concerns").

${ }^{49} I d$. at 21 .

${ }^{50} I d$. at $22-23$. 
I think not, which leads me to adopt a classification system that is explicitly thematic and doctrinal in nature (save for one category that preserves the "procedural" elements of Wigmore/Weisberg). The proposed classification system is set forth below:

A. The Nature of Personhood-legal rules that lead to questions regarding the nature and status of the individual - who is entitled to protection of the law, what is a "person"?

B. Encountering the Other - legal rules governing the relationships among different groups -- social, economic, or species.

C. Dystopianism - legal rules tending to suppress individual rights, thought and freedom.

D. Utopianism - legal rules that seek, often unsuccessfully, to enhance or perfect a species or society.

E. Corporatism - legal rules that enable corporate entities and other mercantile interests to control significant aspects of society.

F. Crime and Punishment - legal rules relating to the definition and punishment of new or existing crimes.

G. Prometheism - legal rules by which society attempts to control the product of its own technological advance and/or to forestall the results of deleterious human activity, whether environmental catastrophe, rampant machines, biological apocalypse, etc.

H. Survivalism - legal rules adopted by the survivors of a major society-altering event - nuclear war, pandemic, environmental collapse, asteroid impact, etc.

I. Procedural - the work depicts a legal procedure, such as a trial, investigation, business transaction or Constitutional convention.

Category A - The Nature of Personhood - is a favorite subject of science fiction authors. It emerged as early as Mary Shelley's genre-defining work Frankenstein (1818), in which the "monster" contemplates the nature, and existence, of its own soul. These existential questions have captivated science fiction authors ever since. Science fiction has explored questions of personhood, consciousness, selfawareness and identity in the context of androids (Westworld, Blade Runner, The Second Renaissance, "Measure of a Man"), artificial intelligence programs (Neuromancer), human clones (Never Let Me Go), and genetically enhanced humans (Generosity, Gattaca). In each of these stories, laws constrain or oppress the individual, leading him/her/it to ponder questions about its own nature. Just as Shakespeare's Shylock, a favorite of the law and literature canon, rails against the laws that oppress his people, "Hath not a Jew eyes?", so do Dr. Moreau's vivisected beast-men ask "Are we not men?" This fundamental question runs through all of the works in this category.

Category B - Encountering the Other - deals with laws that govern the relationships among groups, often those that enable dominant group to subjugate 
another. In some cases, stories in this category may also fall within Category A (e.g., Blade Runner, The Second Renaissance), as androids and members of other oppressed groups may come to question their "humanity". But Category B deals primarily with outward social constraints rather than introspective identity concerns. Laws governing the interaction of species can be portrayed in science fiction as paternalistic, exemplified by Star Trek's Prime Directive, which prohibits representatives of the Federation from interfering with less developed societies, to stabilizing, such as the rules in Men in Black prescribing alien conduct on earth, to downright oppressive. This final category of rules governing the interaction of species is common in science fiction, and often serves as a springboard for the consideration of past and present human rules about slavery, discrimination and racial separation. Derrick Bell makes this comparison explicit in his didactic short story "The Space Traders", though many other works including District 9, Westworld, Blade Runner and The Second Renaissance raise similar issues of enforced $\mathrm{racial} / \mathrm{species}$ separation. ${ }^{51}$

Category $\mathrm{C}$ - Dystopianism - is another common fixture of the science fiction genre. A vast array of evil science fiction empires appear in stories from Flash Gordon to Star Wars. Unfortunately, autocratic states that impose rules that suppress individual rights, thought and freedom are not unique to the realm of fiction, and most depictions of oppressive states in science fiction are thinly-veiled renditions of Nazi Germany, Imperial Britain, Pharaonic Egypt and other autocratic states from human history. The works chosen for this list generally display some oppressive legal structure that has a novel or distinctive aspect, such as Nineteen Eighty-Four (governmental thought control), Fahrenheit 451 (book burning), and The Handmaid's Tale (systemic suppression of women).

Category D - Utopianism - relates to legal rues that seek to promote the enhancement or perfection of a species or society, often at the cost of individual rights or freedom. The envisioned enhancements can be biological (Gattaca, Brave New World), technological ("Nosedive"), psychological (A Clockwork Orange) or social (Elysium, Logan's Run). The common theme, however, is that the perfection-seeking intervention rarely achieves its goal, and often send the desired utopian plummeting into the realm of dystopia.

Category E - Corporatism - many are alarmed by the power of multinational corporations today, and science fiction offers a convenient vehicle to extrapolate current corporate excesses to heady extremes. Corporate entities are among the most sinister characters in science fiction. These include notables such as Tyrell Corporation (Blade Runner), Weyland-Yutani Corporation (Aliens), InGen (Jurassic Park), Tessier-Ashpool S.A. (Neuromancer), Delos Destinations (Westworld), Innovative Online Industries (IOI) (Ready Player One) and CHOAM (Dune). In each case, legal rules or the legal system itself empowers these corporate entities.

${ }^{51}$ See also Mark Bould \& Sherryl Vint, The Routledge Concise History of Science Fiction, Ch. 5 and 7 (2011) (discussing issues of race in science fiction). 
Category F - Crime and Punishment - Science fiction has long had a fascination with crime and its punishment. Stories such as Nineteen Eighty-Four, Brave New World, and A Clockwork Orange contend with the nature of criminal conduct and how it should be defined, while others, such as Shadow of the Torturer, "The Jigsaw Man" and "White Bear", focus on novel methods of criminal punishment as a vehicle for questioning the classification of certain conduct as criminal and the morality of punishment. ${ }^{52}$

Category G - Prometheism - relates to rules that society imposes in order to control its creations - whether dangerous new technologies or environmental collapse. One of the first such tales is Stevenson's Strange Case of Dr. Jekyll and Mr. Hyde, in which Hyde's brutal actions bring him directly into conflict with the criminal laws of the day. More future-looking stories depict rules seeking to constrain or control artificial life forms - androids, robots, AI. These include Neuromancer, I, Robot, Blade Runner and Westworld. Other variants include attempts to control genetic engineering experiments run amok in Jurassic Park, and environmental collapse and overpopulation in Soylent Green.

Category H - Survivalism - these works address legal rules imposed by the survivors of a major society-altering event, usually a catastrophe (pandemic, nuclear holocaust, environmental collapse) that drastically reshapes the contours of human society. ${ }^{53}$ Examples in this list include the societal reorganization that occurs after the sterility plague in Children of Men, the caste system adopted to deal with a seismologically unstable world in The Fifth Season, and the semi-anarchic social structure portrayed in Mad Max Beyond Thunderdome.

Category I - Procedural - these works include as major plot elements the procedural aspects of a legal investigation, case or trial. Numerous Star Trek episodes, for example, involve the (usually false) accusation of a crew member of a crime, and the technical maneuvering that leads to his or her exoneration. The Minority Report imagines a number of futuristic legal procedures, including obtaining an arrest warrant for a crime not yet committed. Kim Stanley Robinson's monumental Blue Mars, on the other hand, depicts nothing less than a full Constitutional convention. Each of these works is interesting not only for the substantive issues that it tackles, but for interesting takes on legal procedure and how it may evolve in the future.

\footnotetext{
${ }^{52}$ For perhaps one of the most chillingly bizarre forms of criminal punishment in science fiction, see China Miéville's Perdido Street Station (2000) in which the guilty are "remade" through the application of twisted science and thaumaturgy into malformed creatures that exist on the edges of society.

${ }^{53}$ See Bould \& Vint, supra note 51, Ch. 5, 8 (discussing apocalyptic fiction of the Cold War era and the 1980s).
} 


\section{Critical Works}

One of Weisberg's greatest contributions to Wigmore's list of legal works was the addition of an appendix cataloging critical works in the then-emerging discipline of law and literature. I have done the same with respect to law and science fiction (see Appendix). By article count (35), this field appears to be at about the same degree of maturity as law and literature was at the time of Weisberg's 1976 catalog.

Critical works concerning law and science fiction have appeared in a range of scholarly outlets, from traditional law reviews to specialized science-technology law journals to literary criticism journals and a few monographs and edited collections. There have been at least two academic symposia on the topic of law and science fiction, which have resulted in published articles as well as informative introductory pieces (Law, Culture and the Humanities (2018) and Legal Studies Forum (1999)), with a third planned for the 2021 annual meeting of the American Association of Law Schools (AALS) (with contributions to be published in Michigan Technology Law Review).

The selection criteria for critical works were straightforward: they must address an issue of law as depicted in a work of science fiction and meaningfully engage with that work of science fiction. Critiques that merely use science fiction tropes as analogies (e.g., an article that compares modern corporations to The Terminator ${ }^{54}$ ) or vaguely describes new technologies (such as human cloning) as "the realm of science fiction" do not qualify, as they do not meaningfully engage with any particular work of science fiction. Likewise, the growing body of academic literature on science fiction (literary criticism, political science, sociology, cultural studies, media studies), much of which appears in the journal Science Fiction Studies based at DePauw University, as well as a handful of edited volumes, is not included unless it contains a significant analysis of legal issues. But so long as these criteria were met, I was relatively lenient regarding the type of work included in this list, ranging from academic articles to long-form journalism to thoughtful blog posts.

Doctrinal approaches in this literature vary. Perhaps the most significant area of study concerns the insights that science fiction literature can offer with respect to race and discrimination law. Professor Derek Bell holds a unique place in this article, as he appears as both the author of the science fiction short story "The Space Traders" (this list), a parable of an alien race that offers to trade gold, environmental decontaminants and safe nuclear energy in exchange for all of the Black residents of the United States, and of various critical commentaries on that work. The story

${ }^{54}$ See Mary Kreiner Ramirez, The Science Fiction of Corporate Criminal Liability: Containing the Machine through the Corporate Death Penalty, 47 ARIZ. L. REV. 933, 934 (2005) ("Although science fiction, The Terminator could conceivably be renamed The Corporation, and with minor changes, such as recasting the corporate lobbyist in Schwarzenegger's role, the current state of corporate dominance could slip right into the plot of the original movie"). 
is also the subject of at least one critical retrospective on critical race theory, also included in this collection. ${ }^{55}$ Other frequent topics of commentary include issues of criminal justice and imprisonment as elucidated through science fiction literature.

In terms of the science fiction works addressed by this literature, the most popular in terms of sheer quantity of references is Star Trek in its various incarnations (original series, The Next Generation, Voyager, etc.). Other popular works in critical commentary are The Dispossessed, Neuromancer, Gattaca, Asimov's robot stories, Dune, Logan's Run, Never Let Me Go and Olivia Butler's Xenogenesis series. Some critical works mention science fiction titles that are not on this list, including various $D r$. Who and X-Files episodes. In general, I have not included these as the stories, while illustrating points about society, politics and human nature, are not explicitly law-related. Others, regrettably, have been omitted due to space constraints.

And now, in the words of Wigmore, "on to the list"! 56

${ }^{55}$ Wing, Adrien Katherine. "Space Traders for the Twenty-First Century." Berkeley Journal of African-American Law \& Policy, vol. 11, no. 1, 2009, p. $49-70$.

${ }^{56}$ Wigmore 1908, supra note 3, at x. 


\section{A LisT OF LEGAL SCIENCE FiCTION WORKS}

Anderson, Michael (dir.)

1. Logan's Run (film) (1976) [C, D]

In the far-future world of the dome, everyone is healthy and comely. The only catch is that everyone must submit to ritual suicide via "Carousel" at the age of 30 . Those who escape are called "runners" and they are hunted down by "sandmen". One such sandman, Logan 5, is assigned to find and destroy a secret sanctuary for runners, but to gain access, his own lifespan clock is advanced by four years, turning him into a legitimate runner. Though dated in some respects, Logan's Run continues to raise provocative issues surrounding utilitarianism, population control, and the price of a perfect society.

Asimov, Isaac

2. I, Robot $(1950)^{57}[\mathrm{~A}, \mathrm{G}]$

Asimov's Three Laws of Robotics ${ }^{58}$ launched an entirely new way of thinking about the interaction between humans and machines, and the Three Laws are still raised today in discussions of AI and machine intelligence. But the overarching lesson of the stories compiled in Asimov's first robot collection, and used in several others, is that no matter how carefully a rule may be designed, situations will arise that challenge a mechanistic application of that rule. As Asimov demonstrates time after time, law is a humanistic endeavor, not a mechanical one.

Atwood, Margaret

3. The Handmaid's Tale $(1985)^{59}[\mathrm{C}, \mathrm{F}]$

A quasi-religious revolution overthrows the U.S. government and transforms the United States into the Republic of Gilead, an authoritarian theocracy. Among the many social changes implemented in the new republic is the reorganization of society along "traditional" gender roles. In particular, women are stripped of the right to own property or money, they are not allowed to read or write, and their reproductive functions are largely dictated by state needs.

\section{Bell, Derrick}

4. "The Space Traders" (story) $(1992)^{60}[\mathrm{~B}]$

The late Constitutional scholar Derrick Bell asks a simple question in his short story "The Space Traders" - if given a choice, would white Americans relinquish to visiting space aliens the entire Black population of the country in exchange for alien technology that could save the environment, end disease and prolong life? Discuss.

${ }^{57}$ I, Robot is a 1950 collection of Asimov's robot-themed short stories, most of which had previously appeared in magazines and other collections. Asimov introduced his famous Three Laws of Robotics in the story "Runaround" (1942). Asimov published several other collections of robot stories, many of which are compiled in The Complete Robot (Doubleday, 1982).

${ }^{58}$ (1) A robot may not injure a human being or, through inaction, allow a human being to come to harm; (2) A robot must obey the orders given it by human beings except where such orders would conflict with the First Law; (3) A robot must protect its own existence as long as such protection does not conflict with the First or Second Law.

${ }^{59}$ See also HBO television series 2017-19.

${ }^{60}$ Despite its 1992 publication date, Professor Bell told the story of the Space Traders on the first day of his Constitutional Law class each year at Harvard Law School for several years before that. I was privileged to be a student in one of those classes and to hear the story as dramatically rendered by its creator. 
Blomkamp, Neill (dir.)

5. District 9 (film) (2009) [B]

This innovative film places the interaction between humankind and the first alien species it encounters not on the battlefield, but in an internment camp. Much of the film was shot in South Africa, and the parallels to apartheid and the issues that it raises are self-evident.

6. Elysium (film) (2013) [D, E]

The trailer for the film Elysium opens with long, panning shots of a high tech paradise - a stylish cross between Beverly Hills and the International Space Station - overlaid with title cards reading "The Year 2154. The privileged live on Elysium. No poverty. No sickness." The shot then cuts to a devastated urban hellscape with teeming hordes clamoring over one another in a dusty postnuclear haze. "The rest of us," the titles inform us, "Live on Earth." Elysium is a timely parable about enforced inequality, immigration and the ever-widening gap between the haves and the have-nots.

Bova, Ben

7. The Dueling Machine (1969) [D, F]

This novella addresses a common theme in science fiction: what if actual conflict could be simulated, and replaced, by virtual conflict? ${ }^{61}$ The dueling machine is an invention that allows two individuals to engage in combat in a virtual environment. Thus, "When two men had a severe difference of opinion, deep enough to warrant legal action, they could go to the dueling machine instead of the courts. Instead of passively watching the machinations of the law grind impersonally through their differences, they could allow their imaginations free rein in the dueling machine .... On most civilized worlds, the results of properly monitored duels were accepted as legally binding." ${ }^{2} 2$ The system works well until the technology is subverted and people begin to die "in real life".

Bradbury, Ray

8. Fahrenheit $451(1953)^{63}[\mathrm{C}]$

Book burning - the willful destruction of knowledge, culture and history - has afflicted societies over the centuries. Bradbury wrote Fahrenheit 451 in response to the rhetoric and tactics of Senator Joseph McCarthy, but the themes that it raises are timeless.

\section{Brooker, Charlie}

9. "Fifteen Million Merits" - Black Mirror (episode) (2011) [C, E]

A near-future society requires its members to pedal stationary bikes all day in order to earn "merits", which they can use for food, entertainment and luxury goods. The only ruling authority appears to be a 3-judge panel from a televised talent show called Hot Shot (which bears a striking resemblance to The X Factor and American Idol). Despite the lack of any explicit recital of the complex internal rules mechanisms that make this society work, they are clearly conveyed through the action.

10. "White Bear" - Black Mirror (episode) (2013) [F]

In this episode, punishment for crime becomes public entertainment, with memory-wiped convicts being inserted into bizarre cosplay scenarios while followed by hordes of paying guests snapping camera phone photos and videos. This episode offers a creative and chilling commentary

${ }^{61}$ Another story addressing this theme is the original Star Trek episode "A Taste of Armageddon" (1967), in which an alien society conducts war using a computer simulation that occasionally requires individuals to report to "disintegration chambers" to be converted into actual casualties.

${ }^{62}$ Ben Bova, The Dueling Machine 27 (1969). Discussed in Walter A. Effross, High-Tech Heroes, Virtual Villains, and Jacked-In Justice: Visions of Law and Lawyers in Cyberpunk Science Fiction, 45 Buffalo L. Rev. 931, 968 (1997).

${ }^{63}$ Bradbury's classic novel has been adapted for film by François Truffaut (1966) and Ramin Bahrani (2018). Neither adaptation does justice to the book. 
on proposals for supplementing funding of the prison system, as well as an increasingly toxic camera phone culture.

11. "Nosedive" - Black Mirror (episode) (2016) [D]

In a world where everything depends on one's 5-star social rating, the consequences of a poor social interaction or an unintended faux pas can be devastating. The implications of such systems are increasingly relevant, particularly as technology brings such systems with the grasp of modern governments (e.g., the social credit system proposed by the Chinese government ${ }^{64}$ ).

Burgess, Anthony

12. A Clockwork Orange $(1962)^{65}[\mathrm{D}, \mathrm{F}, \mathrm{I}]$

In Anthony Burgess's classic novel, the modern psychiatric and criminal justice establishments attempt to reform juvenile delinquent Alex after he commits a string of horrific crimes without apparent motive or gain. Burgess's thoughts about morality, recidivism and youth remain fresh today.

Butler, Octavia

13. Dawn (1987) [B, D]

In the first book of Octavia Butler's award-winning Xenogenesis series, ${ }^{66}$ protagonist Lilith is awakened from suspended animation 250 years after nuclear war has devastated earth. Her captors/saviors are the Oankali, an alien race that wishes to repopulate earth. The only catch is that the Oankali plan to integrate some of their own DNA into that of the surviving humans to create a new and superior species. Dawn presents an unusual twist on the "Encountering the Other" theme, in that the rules governing the interaction of the species are imposed not by humans, but by the Oankali. And those rules are, at least outwardly, surprisingly humane. The Oankali appear to exist in an almost flat, non-hierarchical society (they identify a penchant for hierarchy as one of humanity's weaknesses) that, by and large, is peaceful and just - a sharp contrast to the paranoid and back-stabbing coalition formed by the surviving humans that they awaken.

Cameron, James (dir.)

14. Aliens (film) (1986) [B, E]

A sequel to Ridley Scott's 1979 deep space thriller Alien, Aliens is writer-director James Cameron's masterful rendition of the return mission to destroy the offspring of the creature that terrorized cast and audience in the first film. In the sequel, however, the insidious designs of Weyland-Yutani Corporation slowly become manifest as the potential profit from the alien life forms is weighed repeatedly against the lives of the crew.

Cline, Ernest

15. Ready Player One $(2011)^{67}[\mathrm{E}]$

Like other titles on this list, Ready Player One occurs simultaneously in a near future version of the real world, and a virtual universe in which the characters interact via avatars. The virtual world is essentially a tribute to hundreds of geek cultural icons from the earliest text-based computer games to cryptic rock album liner notes. But it is the "real" world that is the most dangerous for protagonist Wade Watts, who is forced to contend with a host of increasingly aggressive corporate tactics, including a clever reimagination of the private debtors' prison.

${ }^{64}$ See Xin Dai, Enforcing Law and Norms for Good Citizens: One View of China's Social Credit System Project, 63 Development 38 (2020); Gabrielle Bruney, A 'Black Mirror' Episode Is Coming to Life in China, Esquire, 17 March 2018, https://www.esquire.com/newspolitics/a19467976/black-mirror-socialcredit-china/.

${ }^{65}$ See also Stanley Kubrick (dir.), A Clockwork Orange (1971) (film).

${ }^{66}$ Butler's award-winning trilogy (Dawn (1987), Adulthood Rites (1988), Imago (1989)) was originally released as the Xenogenesis series, a name by which it is sometimes referred in the critical literature. Today, it is marketed as Lilith's Brood.

${ }^{67}$ See also Steven Spielberg, Ready Player One (film) (2018). 
Collins, Suzanne

16. The Hunger Games (film) $(2008)^{68}$ [C]

The universe of Suzanne Collins's Hunger Games revolves around one central and all-important rule: every year, twelve vassal districts ruled by a central Capital must send two teenage "tributes" to participate in a gladiatorial contest that will result in only one of them surviving.

\section{Crichton, Michael}

17. Westworld (film and series, Season 1) $(1973,2016)^{69}[\mathrm{~A}, \mathrm{E}]$

The underlying premise of the original Westworld film and the currently-running HBO series is that people will pay a great deal to visit a theme park where they are unbound by the laws that govern ordinary society. In particular, where they are free to kill, maim and abuse the park's resident android "hosts", which are quickly repaired each night for the next day's entertainments. But neither the park's creators, nor its guests, are adequately prepared for the realization that the hosts may have developed a consciousness of their own, and that they do not like how they are treated.

18. Jurassic Park (1990) ${ }^{70}[\mathrm{E}, \mathrm{G}]$

Michael Crichton's iconic novel Jurassic Park is a cautionary tale about the perils of genetic engineering and corporate greed. In addition to a wealth of plot devices centering on the corporate legal strategies of InGen and those who want to steal the secret of its genetically-resuscitated dinosaurs, the film version of Jurassic Park contains one of the best scenes involving a lawyer in the history of cinema.

19. NEXT (2006) [E]

Sixteen years after Jurassic Park, Michael Crichton revisits genetic engineering and a range of other biotechnology advances in this uneven novel. It is listed here because the book takes on several legal issues that, according to Crichton, enable the types of mad scientist depredations depicted in the novel. Chief among these is "gene patenting", against which the author rails in an Appendix to the text.

\section{Dick, Philip K.}

20. A Scanner Darkly (1977) [C, F]

The convoluted plot of Philip K. Dick's disturbing novel A Scanner Darkly revolves around a narcotics agent who is assigned to inform on a ring of drug users and dealers, of which he is a member and, perhaps, the leader. In Dick's dystopian world, surveillance is pervasive, law enforcers are anonymous, and paranoia is the norm.

Eggers, Dave

21. The Circle (2013) [D, E]

David Eggers's dystopian vision of the near future involves pervasive surveillance provided by huge corporate enterprises that view themselves, perhaps cynically, as giving consumers what they want. As the technology offered by The Circle, the mega-company at the center of the novel, evolves to include always-on audiovisual feeds of everyone all the time, the predicted benefits -crime prevention, political transparency -- fail to materialize.

${ }^{68}$ See also Suzanne Collins, Catching Fire (2009) and Mockingjay (2010), and Gary Ross (dir.), The Hunger Games (film) (2012).

${ }^{69}$ Michael Crichton directed and wrote the 1973 Westworld film starring Yul Brynner as a murderous rogue android in a Wild West themed amusement park. Crichton's film is also the basis for the 2016 HBO series Westworld created by Jonathan Nolan and Lisa Joy. Season 1 of the series loosely tracks the plot of the 1973 film. Later seasons of the series (which remains in production as of this writing) diverge from the original story line.

${ }^{70}$ See also Steven Spielberg (dir.), Jurassic Park (1993) (film). 
Fleischer, Richard (dir.)

22. Soylent Green (film) $(1973)^{71}[\mathrm{E}, \mathrm{G}]$

In the 2022 of this classic dystopian film, Garret Hardin's "tragedy of the commons"72 has already occurred -- over-population, environmental degradation and climate instability have pushed earth and human society over the brink of collapse. Contending with these issues, the government has established euthanasia centers where those weary of the world's troubles can exit gracefully, accompanied by soothing images of long-gone forests and the strains of Beethoven's Pastoral Symphony. What happens with their bodies afterwards is the subject of the film's iconic reveal.

\section{Gibson, William}

23. Neuromancer (1984) [A, E, G]

In the dark cyberpunk future of Neuromancer, the world is ruled by wealthy, cloned oligarchs and the entire east coast from Boston to DC is a single mega-city called The Sprawl. The development of AI is strictly regulated by the Turing Police. Wintermute, a shadowy AI with Swiss citizenship, clandestinely recruits a gang of human cyber cowboys to reunite it with its twin, Neuromancer. When the plot is discovered by the Turing Police, one officer explains, "For thousands of years men dreamed of pacts with demons. Only now are such things possible. And what would you be paid with? What would your price be, for aiding this thing to free itself and grow?" Despite its age, Neuromancer still offers one of the most compelling visions of cyberspace and AI in all of literature.

Herbert, Frank

24. Dune $(1965)^{73}[\mathrm{~B}, \mathrm{D}, \mathrm{E}]$

In Dune, Frank Herbert creates a richly-textured universe replete with complex political structures, religious orders and commercial concerns. A Byzantine system of formal and informal rules govern the roles of the powerful sects, factions and governments that interact within Herbert's universe.

Huxley, Aldous

25. Brave New World (1932) $)^{74}$ [A. C, D, F]

Huxley's landmark eugenic dystopian novel depicts a society carefully structured through a panoply of social control regulations $-70 \%$ of women must be sterile; infants are classified by intellectual capability into castes that dictate their future careers and social status; and dissidents are banished to remote islands. The plot follows the entry of a "savage" outsider into this society and tracks his rise and eventual fall.

\section{Ishiguro, Kazuo}

26. Never Let Me Go $(2005)^{75}$ [A, D]

Kazuo Ishiguro's novel Never Let Me Go is, in my view, the most poignant and heartrending exemplar of the compelled-organ-harvesting theme. It concerns a group of friends at what, at first, appears to be a genteel English public school. Yet it soon becomes clear that the children at Halisham School are clones created for the sole purpose of "donating" their organs to others. The legal and political reasoning that led here, and the ethical qualms of some of the system's administrators, provide ample food for thought.

${ }^{71}$ The film is loosely based on Harry Harrison, Make Room! Make Room! (1966).

${ }^{72}$ See Garret Hardin, The Tragedy of the Commons, Science (1968).

${ }^{73}$ Numerous film and television adaptations of the Dune novels exist, most notably David Lynch's serviceable 1984 version starring Kyle MacLachlan and Sting. More interesting, however, is Jodorowsky's Dune, Frank Pavich's 2013 American-French documentary describing the abortive attempts by avant-garde director Alejandro Jodorowsky to make a 10-12 hour adaptation of Dune with a cast including art and film world icons Salvador Dali, Orson Welles, Gloria Swanson, David Carradine and Mick Jagger. Highly detailed information about Herbert's intricate Dune universe can be found in Willis E. McNelly, The Dune Encyclopedia (1984).

${ }^{74}$ See also Brave New World (series) (Peacock, 2020)

${ }^{75}$ See also Mark Romanek (dir.), Never Let Me Go (2010) (film). 
James, P.D.

27. The Children of Men (1992) ${ }^{76}[\mathrm{C}, \mathrm{H}]$

This beautifully rendered novel poses the chilling question: what would happen if the entire human race suddenly became infertile? The novel opens 25 years after that still unexplained event, known as Omega. In response, the British government has enacted laws gradually recognizing the inevitable demise of the human species. Early measures such as razing public playgrounds and fining the families of suicide victims eventually give way to what is effectively a state-sponsored retirement community, with government-provided golf courses and massage therapy centers available to an aging and despairing population. Crime in Britain plummets once the Isle of Man is repurposed as a penal colony, and most ordinary citizens seem content to wait out the clock pursuing hobbies and meaningless pastimes. But more sinister currents emerge as the reader learns about forced immigrant labor, mass euthanasia and the increasingly authoritarian government. Is it enough for the state to provide a despairing populace with "protection, comfort and pleasure"? Or should it strive, as one dissident group believes, for "compassion, justice and love"?

Le Guin, Ursula K.

28. The Dispossessed (1974) [B, D]

LeGuin's landmark novel portrays the human societies of twin planets - Urras and Anarres. While Urras society resembles that of earth in many respects (capitalistic, bellicose), Anarres was settled by political dissidents two centuries earlier. The society that they build is a sort of socialist utopia in which private property does not exist, crime is virtually unknown and even locks on doors are unfamiliar. ${ }^{77}$ In one extended sequence, a group of children on Anarres learns about the prisons on Urras. Puzzled, they construct a "locked" room under their school in which one of their number volunteers to experience imprisonment. The result is embarrassing but informative. The Dispossessed offers numerous similar opportunities to reevaluate existing legal rules and norms in view of Le Guin's alternatives.

\section{Lessing, Doris}

29. Re: Colonised Planet 5, Shikasta (1979) [B]

In Shikasta, the first book in Doris Lessing's Canopus in Argos series, Lessing draws on her upbringing in Rhodesia (now Zimbabwe) to confront issues of colonialism and cultural imperialism. The novel traces the 30,000-year involvement of agents of the Canopean empire with Shikasta (Earth). From the Canopean perspective, the history of Shikasta reflects a series of bad decisions made by its rulers and people - it is only the benign intervention of Canopus and its agents that have repeatedly pulled humanity from the brink of destruction. ${ }^{78}$ Toward the end of the novel, the Chinese officials who now run Europe stage a "mock trial" in which the "white races" are indicted for "The conquest of brilliant civilisations through rapacity, greed, guile, trickery. The savagery of Christianity. The subjection of the Indians. The introduction of black people from Africa, the slave trade. The devastation of the continent, its resources, its beauty, its wealth", and so on. ${ }^{79}$ The lead counsel for the prosecution is a Canopean agent, George Sherban, who is posing as a college lecturer on "Systems of the Law." The outcome of the trial is inconclusive, but is followed in short order by World War III, which devastates the planet and kills $99 \%$ of its population. But hope is reborn through a renewed linkage between Canopus and the wayward Shikasta (Earth).

${ }^{76}$ See also Alfonso Cuarón (dir.), The Children of Men (film) (2006).

77 The world of The Dispossessed has been the subject of substantial critical commentary. See, e.g., James F. Collins, "The High Points So Far: An Annotated Bibliography of Ursula K. LeGuin's The Left Hand of Darkness and The Dispossessed", Bulletin of Bibliography, v.58, no.2, pp. 89100 (June 2001).

${ }^{78}$ Critics have been uneasy with Lessing's seeming approval of Canopus's benign colonialism. See Ruth Whittaker, Doris Lessing 100-01 (1988).

${ }^{79}$ Doris Lessing, Re: Colonised Planet 5, Shikasta 323 (1979). 
Liu, Ken

30. "Byzantine Empathy" (story) $(2018)^{80}[\mathrm{E}]$

In a remarkably short space, this story weaves together virtual reality, smart contracts and cryptocurrencies in an engaging parable about the future of philanthropy and its impact on geopolitics. As a bonus, the story gives a shout out to a recent law review article that addresses these and many more emerging legal issues raised by VR. ${ }^{81}$

Lucas, George

31. THX 1138 (film) (1971) [C]

George Lucas's first film depicts a whitewashed dystopian future in which sexual relations and procreation are banned. The arrest and imprisonment of the principal characters, THX 1138 and LUH 3417, for violating these societal strictures bear some similarities to the events depicted in Nineteen Eighty-Four, but Lucas's work is far less cerebral, and concludes with a chase sequence that is more evocative of Logan's Run than Nineteen Eighty-Four. Nevertheless, a half century after its release, $T H X 1138$ continues to offer an interesting and influential perspective on the laws that shape a tightly-controlled dystopia.

Maeda, Mahiro

32. The Second Renaissance (short film) $(2003)^{82}$ [A, B]

This animated prequel to The Matrix films, though little known, is a tour de force of legal science fiction. It casts the history of the machine-human war that led to the events in The Matrix, in terms of the struggle for civil rights by sentient machine servants (read: slaves) created by humans. When a renegade machine kills a human, it is put on trial in a proceeding that evokes both Richard Wright's Native Son and the 1856 case Dred Scott v. Sanford. Next come social unrest, riots, genocide, diaspora and war. As anyone who has watched the Matrix films must appreciate, humankind does not come out ahead after these events.

Miller, George (dir.) $)^{83}$

33. Mad Max Beyond Thunderdome (film) (1985) [F, H]

The post-apocalypse survival story is among science fiction's most distinguished sub-genres, with classics including Cormac McCarthy's The Road, Russel Hoban's Ridley Walker, Pat Frank's Alas, Babylon, and Emily St. John Mandel's recent Station Eleven. Mad Max Beyond Thunderdome is not among these greats. However, it is the only such tale to include the name of a futuristic legal institution in its title. The semi-barbaric Bartertown is governed according to a set of bright line rules such as "Two men enter, one man leaves" and "Bust a deal, face the wheel". These simple strictures are enforced by Tina Turner -- who rose from nothing to become Bartertown's badass despot - and her gang of henchmen. Though only the first thirty minutes or so of this film are worth watching, they earn the third installment of the Mad Max franchise a place on this list.

Moore, Ronald D.

34. "Sins of the Father" Star Trek TNG (episode) $(1987)^{84}[\mathrm{I}]$

Lieutenant Worf, a Klingon serving on the Enterprise, is required to stand trial before the Klingon High Council for an alleged act of treason by his father more than twenty years earlier. Yet the evidence is contained in electronic communication records that appear difficult to gainsay. The

${ }^{80}$ First appeared in Twelve Tomorrows (Wade Roush, ed., MIT Press, 2018), also available in BreakerMag, Sep. 28, 2018, https://breakermag.com/kchain-science-fiction-premiere-byzantineempathy/.

${ }^{81}$ Mark A. Lemley \& Eugene Volokh, Law, Virtual Reality, and Augmented Reality, 166 U. Penn. L. Rev. 1051 (2018).

${ }^{82}$ The Second Renaissance, Parts 1 and 2, was released as part of the animated compilation titled The Animatrix (Warner Home Video, 2003). It forms a prequel to the Matrix series of films.

${ }^{83}$ Co-directed with George Ogilvie.

${ }^{84}$ Co-written with W. Reed Moran. 
proceedings introduce interesting questions regarding conflict of laws (Federation vs. Klingon), as well as evidence and burdens of proof in an era where "deep fakes" can be manufactured to look like records of past events. ${ }^{85}$

Niccol, Andrew (dir.)

35. Gattaca (film) (1997) [A, D]

The decades old film Gattaca has aged remarkably well, and the difficult questions that it raises about genetic determinism, discrimination, eugenics and human capacity are even more relevant today than they were when the film was made. ${ }^{86}$

Niven, Larry

36. "The Jigsaw Man" (story) (1967) [F]

Niven's short story is one of the best exemplars of the compulsory-organ-donation genre, this time inflicted on convicted criminals. Despite its brevity, the story offers ample grist for considering issues of guilt, punishment and utilitarianism.

Orwell, George

37. Nineteen Eighty-Four $(1949)^{87}$ [A, C, F]

The archetype dystopian novel, Orwell's masterpiece portrays an authoritarian state that strives to control not only its citizens' actions, but their very thoughts. Orwell's bleak vision encompasses devices that are only too real today, including the surveillance state, the malleability of "facts", and the determinism of language.

Powers, Richard

38. Generosity: An Enhancement (2009) [A, E]

Thassadit "Thassa" Amzwar, an Algerian refugee living in Chicago, has seen overwhelming tragedy during her short life, yet seems to exist in an inexplicable state of perpetual bliss. When Thassa's creative writing instructor diagnoses her condition as "hyperthymia", a string of attempts to co-opt her unique genetic recipe for happiness are perpetrated by the scientific and corporate establishment.

\section{Robinson, Kim Stanley}

39. Blue Mars $(1996)^{88}[\mathrm{E}, \mathrm{I}]$

The third installment in Kim Stanley Robinson's magisterial future history of the colonization of Mars and the rest of the solar system offers a sweeping view of the legal and political structures that are likely to exist a century hence. These resonate strikingly with those that we face today, including deep divides over immigration and environmental protection. The book depicts, in convincingly realistic detail, the debates over a new constitution for Mars, which results in a recognizable yet distinctly alien system of government (including a system of "environmental" courts). Of all the works on this list, I consider Robinson's the one that depicts events that are most likely actually to happen.

\section{Roddenberry, Gene}

40. "The Menagerie, Parts 1 and 2" - Star Trek (episode) (1966) [B, I]

In this iconic Star Trek double episode, Mr. Spock is the subject of a court martial for disobeying Starfleet General Order 7 -- "No vessel under any condition, emergency or otherwise, is to visit

${ }^{85}$ The need to refute seemingly airtight computer evidence is a frequent theme on Star Trek. See also "Court Martial" Star Trek TNG (1967) (Capt. Kirk is accused of culpable negligence on the basis of computer records that contradict his personal testimony) and "Ex Post Facto" Star Trek Voyager (1995) (Lt. Paris is accused of murder on the basis of a preserved memory from the victim).

${ }^{86}$ In the genetics ethics class that I teach to medical students, my co-instructor counts the minutes before someone mentions Gattaca during class discussion. The count is never very high.

${ }^{87}$ See also Michael Radford (dir.), Nineteen Eighty-Four (1984) (film).

${ }^{88}$ See also Kim Stanley Robinson, Red Mars (1992), Green Mars (1993). 
Talos IV." Spock seeks to justify his violation of this clear Starfleet prohibition, which carries the penalty of death, on essentially humanitarian grounds.

41. "The Omega Glory" - Star Trek (episode) (1968) [B, H]

When an Enterprise landing party beams down to planet Omega IV, they have been preceded by Captain Ron Tracey of the USS Exeter. Tracey, who has armed a local tribe with phasers, appears to have violated the Prime Directive, which prohibits Federation personnel from interfering with alien cultures that they encounter. Eventually, another local tribe reveals that it venerates a copy of the U.S. Constitution, which its leaders recite in unintelligible pidgin until Kirk dramatically explains the "true" meaning of the document to them. The episode has been criticized for its racial stereotypes, but still offers interesting food for thought regarding the Prime Directive, cold war tensions, and. Perhaps, Constitutional textualism.

Scott, Ridley (dir.)

42. Blade Runner (film) $(1982)^{89}$ [A, B, E]

In a bleak near-future, lifelike replicants are created to perform dangerous off-world work, but are prohibited from returning to earth. If they do, special police units called Blade Runners are trained to identify and terminate them. The plot revolves around one Blade Runner's hunt for six powerful replicants that have returned to earth to seek a cure for their built-in termination dates. The interest of the film lies in the unsettling questions that it raises about the nature of humanity and consciousness, and the justness of laws that condemn the superhuman replicants.

\section{Serling, Rod}

43. "The Obsolete Man" - Twilight Zone (episode) (1961) [C, I]

In a future totalitarian state, an aging librarian is sentenced to death because he is "obsolete" (as there are no more books). The interest of the episode comes, however, in the manner of execution that the condemned man selects, and how he subtly twists it to his own designs.

\section{Snodgrass, Melinda M.}

44. "The Measure of a Man" - Star Trek TNG (episode) (1989) [A, I]

In this episode written by Melinda Snodgrass, a former attorney and regular contributor to the show, an ambitious Federation cyberneticist wishes to disassemble Commander Data to determine the secrets of his positronic brain (Data was created by the legendary Dr. Noonien Soong before being killed). Data, unimpressed with the researcher's capabilities, refuses the request, which leads to a military hearing at which the tribunal must determine whether Data is a sentient being entitled to refuse such a request, or a mechanical piece of Starfleet property. The proceeding raises a host of thought-provoking issues touching on the rule of law, the meaning of sentience, and the right to "own" another thinking being (with references to slavery being explicit). There are notable echoes of the original Star Trek episode "Court Martial" (see above), including a presiding JAG officer who had a history with the Enterprise's captain, and a debate over the inclusion of Data's many Starfleet commendations in the record.

\section{Sonnenfeld, Barry (dir.)}

45. Men in Black $(1997)^{90}[\mathrm{~B}]$

Men in Black is premised on both the existence of (disguised) extraterrestrial aliens among us, and an elaborate set of rules and procedures that dictate how such aliens must conduct themselves while on earth so as to remain almost entirely unknown to the human population at large. The Men in Black - a secret quasi-governmental organization - exists to monitor and enforce compliance with these rules, and has a variety of technologies at its disposal to assist in this difficult task.

${ }^{89}$ See also Philip K. Dick, Do Androids Dream of Electric Sheep (1968) (novel).

${ }^{90}$ See also Lowell Cunningham and Sandy Carruthers, The Men in Black (1990) (comic). 
Spielberg, Steven (dir.)

46. Minority Report $(2002)^{91}$ [F, I]

In the mid- $21^{\text {st }}$ century, a state program to care for the impaired children of drug addicts discovers that some of the children have visions of future murders. The three children that survive this program are turned into semi-conscious "precogs" that float in a nutrient bath and help the DC police department stop homicides before they occur. Once caught, the would-be perpetrators are suspended in subterranean fluid capsules where they are forced to watch the captured images of their thwarted crimes in an infinite loop while their jailer plays soothing Bach arrangements on a small pipe organ. According to the police, there hasn't been a murder in DC during the six years of the successful Precrime program. Not surprisingly, problems emerge.

Stevenson, Robert Louis

47. The Strange Case of Dr Jekyll and Mr Hyde (1886) [A, F]

Stevenson's blockbuster $19^{\text {th }}$ century tale of dual personality and the nature of evil begins with the words, "Mr. Utterson, the lawyer, was a man of a rugged countenance, that was never lighted by a smile..." Utterson is Dr. Henry Jekyll's personal attorney and has become concerned that his client has recently made a crude man named Edward Hyde the sole beneficiary of his will. Utterson gradually learns the true relationship between Jekyll and Hyde, serving as witness and interlocutor to the story's main characters.

Vlaming, Jeff

48. "Litmus" - Battlestar Galactica episode (2005) [A, B, H, I]

In this episode from the first season of the Battlestar Galactica reboot, a Cylon agent infiltrates the Galactica and commits an act of sabotage. Commander Adama appoints Master at Arms Sargent Hadrian to conduct an investigation of the incident and to convene an independent tribunal to consider the evidence. That evidence, however, points in ambiguous directions as crew members dissemble to protect Chief Tyrol, whose is involved in an illicit affair with Sharon "Boomer" Valerii, a Galactica pilot who is, unbeknownst to all, a Cylon herself. The episode raises interesting issues concerning the rule of law, particularly when Adama unilaterally terminates the tribunal as a "witch hunt". Underlying the tribunal plot are deeper currents concerning the colonists' newfound knowledge that Cylons have taken human form and the general paranoia that knowledge engenders.

Wells, H.G.

49. The Island of Doctor Moreau (1896) [A, G]

On a remote island in the South Pacific, the eccentric physiologist Dr. Moreau creates a race of half-animal, half-human creatures. To suppress their bestial natures, and nudge them toward humanity, he imposes on them a strict set of "laws" that they must periodically chant: "Not to go on all-fours; that is the Law. Are we not Men? Not to suck up Drink; that is the Law. Are we not Men?" and so forth. Yet the beast-people have difficulty adhering to these rules, particularly after dark. This early science fiction work raises difficult issues concerning the nature of humanity and the role of law in civilized society.

Wolfe, Gene

50. Shadow of the Torturer (1980) [F]

On a far-future earth, criminal punishment has been delegated to the ascetic Seekers for Truth and Penitence, more commonly known as the Guild of Torturers, who take pride, but no pleasure, in the fiendish punishments that they mete out to the guilty and less so. Wolfe's universe is a mélange of medieval ritual and alien technology, where the rules of the world are only glimpsed peripherally, but shape virtually every action of its inhabitants.

${ }^{91}$ See also Philip K. Dick, “The Minority Report” (1956) (novella). 
Electronic copy available at: https://ssrn.com/abstract=3647579 


\section{ADDENDUM - CRITICAL WORKS}

1. Bell, Derrick. "The Power of Narrative." Legal Studies Forum, vol. 23, no. 3, 1999, p. 315348.

2. --- "Justice Marshall and the Handmaid's Tale." Afrolantica Legacies, Chicago, IL: Third World Press, 1997, p. 123.

3. Ben-Naftali, Orna and Zvi Triger. "The Human Conditioning: International Law and Science-Fiction." Law, Culture and the Humanities, vol. 14, no. 1, 2018, pp. 6-44.

4. Brean, Daniel H. "Keeping Time Machines and Teleporters in the Public Domain: Fiction as Prior Art for Patent Examination." Pittsburgh Journal of Technology Law \& Policy, vol. 7, 2007, pp. 1-38.

5. Brown, Christopher. "Will There Be Justice? Science Fiction and the Law." Tor, Aug. 7, 2019.

6. Bruney, Gabrielle. "A 'Black Mirror' Episode Is Coming to Life in China”, Esquire, 17 March 2018, https://www.esquire.com/news-politics/a19467976/black-mirrorsocialcredit-china/.

7. Buckner Inniss, Lolita K. "Bicentennial Man - The New Millennium Assimilationism and the Foreigner Among Us." Rutgers Law Review, vol. 54, 2002, p. 1101-.

8. Burling, William J. "The Theoretical Foundation of Utopian Radical Democracy in Kim Stanley Robinson's Blue Mars.” Utopian Studies, Vol. 16, No. 1, Spring 2005, pp. 75-96.

9. Contreras, Jorge L. "Book Review: NEXT and Michael Crichton's Five-Step Program for Biotechnology Law Reform." Jurimetrics, vol. 48, no. 3, 2008, 337-348.

10. Corcos, Christine Alice. "I am Not a Number - I am a Free Man: Physical and Psychological Imprisonment in Science Fiction." Legal Studies Forum, vol. 25, no. Issues $3 \& 4,2001$, p. 471-484.

11. Corcos, Christine, Isabel Corcos and Brian Stockhoff. "Double-Take: A Second Look at Cloning, Science Fiction and Law." Louisiana Law Review, vol. 59, no. 4, Summer 1999, p. 1041-1100.

12. Effross, Walter A. "High-Tech Heroes, Virtual Villains, and Jacked-In Justice: Visions of Law and Lawyers in Cyberpunk Science Fiction." Buffalo Law Review, vol. 45, no. 3, Fall 1997, p. 931-974.

13. Gemmette, Elizabeth Villiers, ed., Law in Literature: Legal Themes in Short Stories (New York: Praeger, 1992).

14. Hallevy, Gabriel. "The Criminal Liability of Artificial Intelligence Entities - From Science Fiction to Legal Social Control." Akron Intellectual Property Journal, vol. 4, no. 2, 2010, p. 171-202.

15. Joseph, Paul, and Sharon Carton. "The Law of the Federation: Images of Law, Lawyers, and the Legal System in Star Trek, the Next Generation." University of Toledo Law Review, vol. 24, no. 1, Fall 1992, p. 43-86.

16. Kerr, Ian and Katie Szilagyi. "Evitable Conflicts, Inevitable Technologies? The Science and Fiction of Robotic Warfare and IHL." Law, Culture and the Humanities, vol. 14, no. $1,2018,45-82$.

17. Laurence, Robert. "Civil Procedure in Low Earth Orbit: Science Fiction, American Indians and Federal Courts." New Mexico Law Review, vol. 24, no. 2, Spring 1994, p. 265-284.

18. Lavender III, Isiah. Race in American Science Fiction. Bloomington, IN: Indiana University Press, 2011.

19. Lavi, Shai. "Cloning International Law: The Science and Science Fiction of Human Cloning and Stem-Cell Patenting." Law, Culture and the Humanities, vol. 14, no. 1, 2018, 83-89.

20. Leslie-McCarthy, Sage. "Asimov's Posthuman Pharisees: The Letter of the Law Versus the Spirit of the Law in Isaac Asimov's Robot Novels." Law, Culture and the Humanities, vol. 3, 2007, p. 398-415. 
21. Nelson, Anna Lorien, and John S. Nelson. "Institutions in Feminist and Republican Science Fiction." Legal Studies Forum, vol. 22, no. 4, 1998, p. 641-654.

22. Nesteruk, Jeffrey. "A New Narrative for Corporate Law." Legal Studies Forum, vol. 23, no. 3, 1999, p. 281-292.

23. Raiford, Wanda. "Race, Robots and the Law." New Boundaries in Political Science Fiction, Donald M. Hassler, Clyde Wilcox, eds., Univ of South Carolina Press, 2008, p. 93-112.

24. Rockwood, Bruce L. "Law, Literature and Science Fiction: New Possibilities." Legal Studies Forum, vol. 23, no. 3, 1999, p. 267-280.

25. Scharf, Michael P. and Lawrence D. Roberts. "The Interstellar Relations of the Federation: International Law and Star Trek - The Next Generation." University of Toledo Law Review, vol. 25 , no. 3, 1994, p. 577-616.

26. Stewart, Chip. "Do Androids Dream Of Electric Free Speech? Visions of the Future Of Copyright, Privacy And The First Amendment In Science Fiction." Communication Law and Policy, vol. 19, Autumn 2014, p. 433-

27. Tranter, Kieran. Living in Technical Legality: Science Fiction and Law as Technology. Edinburgh: Univ. of Edinburgh Press, 2018.

28. -- "The Speculative Jurisdiction: The Science Fictionality of Law and Technology." Griffith Law Review, vol. 20, no. 4, 2011, p. 817-850.

29. --- "Terror in the Texts: Technology - Law - Future," Law \& Critique, vol. 13, no. 1, 2002 p. $75-$.

30. Travis, Mitchell. "Making Space: Law and Science Fiction." Law and Literature, vol. 23, no. 2, Summer 2011, p. 241-261.

31. Travis, Mitchell, and Kieran Tranter. "Interrogating Absence: The Lawyer in Science Fiction." International Journal of the Legal Profession, vol. 21, no. 1, March 2014, p. 2338.

32. de Villiers, J.H. and M. Slabbert. "Never let me go: science fiction and legal reality." Literator, vol. 32, no. 3, Des./Dec. 2011, p. 85-103.

33. Ward, Ian. Law And Literature: Possibilities And Perspectives. New York: Cambridge University Press, 1995.

34. Weld, Daniel and Oren Etzioni. "The First Law of Robotics (a call to arms)." AAAI-94 Proceedings, 1042-1047.

35. Wing, Adrien Katherine. "Space Traders for the Twenty-First Century." Berkeley Journal of African-American Law \& Policy, vol. 11, no. 1, 2009, p. 49-70.

36. Wingfield, Thomas C. "Lillich on Interstellar Law: U.S. Naval Regulations, Star Trek, and the Use of Force in Space." South Dakota Law Review, vol. 46, no. 1, 2001, p. 72-101. 